\title{
Civilizational and Cultural Approaches to the Constructing of the Education Content in Kazakhstan
}

\author{
Perizat Baiteshovna Seitkazy ${ }^{1}$, Kamariyash Raikhanovna Kalkeyeva ${ }^{1}$, Roza Khussainovna Aimagambetova ${ }^{1}$, \\ Nurilya Sabetkanovna Kassymbekova ${ }^{1}$, Tashetov Amanzhol Askarovich ${ }^{1} \&$ Gulnur Sabetkanovna Jexembayeva ${ }^{1}$ \\ ${ }^{1}$ L. N. Gumilyov Eurasian National University, Astana, Kazakhstan \\ Correspondence: Perizat Baiteshovna Seitkazy, Munaytpasova street 5, Astana, 010000, Republic of Kazakhstan
}

\author{
Received: February 28, 2015 Accepted: March 20, 2015 Online Published: April 24, 2015 \\ doi:10.5539/res.v7n6p100 URL: http://dx.doi.org/10.5539/res.v7n6p100
}

\begin{abstract}
In this article extremely understudied problem - the development of educational content is considered. Studying of this problem at the present stage, according to the authors, creates conditions for the development and realization of basic methodological guidelines, provides the scientific worldview, allows to trace the genesis of pedagogical positions, pedagogical theories. Combining the two approaches in a single article the authors attempted to determine that the civilizational and cultural approaches have common characteristics. Civilization is a general evaluation of the social culture of life that allows you to "quite organically carry civilizational approach to the field of the world educational process, in the center of which man stands, who is educated and teaches, who develops culture created by previous generations, and transforming himself and the culture in the course of this development". Civilizational and cultural approaches provide a fundamental rethinking of the role and importance of the education system of Kazakhstan.

Opinions of different authors of different historical are reviewed and compared. Such terms as "world civilizations", "civilization", and "culture" are disclosed. Each term has a special meaning, character, manifested in different aspects science. Also the essential characteristic of the basic concepts and positions of pedagogy are considered.
\end{abstract}

Keywords: civilizational approach, cultural approach, educational content, local civilization, phasic civilization, world civilization

\section{Introduction}

Independence of any science including the history of education and pedagogy is defined by special subject of research and by methodology, what serves as a reliable tool to ensure science's continuous, ascending genesis. We share the view of G. M. Hrapchenkov and V. G. Hrapchenkov that "the problems of methodology in conducting educational, historical and educational researches are the key components of learning of phenomena upbringing and education"; that methodological amateurism leads to a distortion and falsification of objective reality (Hrapchenkov \& Hrapchenkov, 1998). Methodology is a theory of scientific and cognitive activity aimed at research and development of methods of scientific knowledge. It is the part of epistemology, the general theory of knowledge, which serves as the teaching methods of the theory of knowledge or research methods (Taubayeva, 2007). Currently actively civilizational approach to the study of the genesis of the educational process is developed. One of its supporters, G. B. Kornetov believes that civilizational approach may become an integral factor in the synthesis of various sciences, it allows to analyze pedagogical phenomenon from different epochs in comparative terms. In his opinion, the hypothesis of a civilizational approach "has considerable heuristic potential" (Kornetov, 1994). A. Toynbee, E. Mayers considered civilization as a socio-cultural organism, and education as one of its sides. The role of education in the history of civilization was considered as significant.

The subject of the civilizational approach is "the set of all norms of human life in their historical development and continuity" or "as something that can be called civilization in its local or broader sense-until to human-general expression" (Pozdnyakov, 1990).

Civilizational approach is an alternative to the previously prevailed in the historical and pedagogical research formational approach. It treats each formation as a stage in the development of civilization, trying to explore the 
pedagogical phenomena on the background of socio-economic and socio-political dynamics of society, overcomes the limitations (Osadchaya, 1991).

What about cultural approach. Firstly researcher should define the word "culture". Culture has been defined as "The system of values, beliefs, and ways of knowing that guide communities of people in their daily lives" (Trumbull, 2005). Effective teacher preparation addresses the need for teachers to acknowledge students' diversity and incorporate their pluralistic backgrounds and experiences into the learning experiences and classroom environment. In "culturally relevant pedagogy" (Ladson-Billings, 2001), "culturally responsive teaching" (and other similar terms) (Gay, 2000) teachers "develop the knowledge, skills, and predispositions to teach children from diverse racial, ethnic, language, and social class backgrounds" (Weinstein, Curran, \& Tomlinson-Clarke, 2003). Kirk-land commented that "good multicultural teaching honors our diverse cultural and ethnic experiences, contributions and identities" and emphasized that teachers need to "understand the experiences and perspectives (students) bring to educational settings and be responsive to the cultures of different groups in designing curriculum, learning activities, classroom climated, instructional materials and techniques, and assessment procedures".

According to Hackett, teachers need to develop a "strong cultural identity (so as to be) responsible for teaching the whole child by teaching values, skills, knowledge for school success and participation in society, linking classroom teaching to out-of-school personal experiences and community situations" (Hackett, 2003). Ambrosio emphasizes the importance of multiculturalism for the teacher:

Teaching is learning - a process of slowly integrating knowledge into practice... The most important aspect of teaching is developing the mental habit of reflecting on your instructional practice and of altering your practice according to what you discover about how students learn best. Knowledge of multicultural theory and practice will give you the reflective space, the necessary reservoir of cultural insight, to intelligently address pedagogical issues as they arise in your everyday practice (Ambrosio, 2003).

Gay (2006) echoed one recurring response to the need to ensure high-quality teacher preparation, "U.S. society is becoming increasingly diverse, and that diversity is reflected in its classrooms. Creating a respectful, productive classroom environment is always a challenge; this challenge is even greater when students and teachers come from different cultural backgrounds, or when students differ in terms of race, ethnicity, socioeconomic status, cultural and linguistic background, sexual orientation, ableness, and academic aptitude. Unless teachers have the knowledge, skills, and disposition to effectively guide diverse groups of children, they are likely to face classes characterized by disrespect and alienation, name-calling and bullying, disorder and chaos".

Culturally relevant pedagogy aims to ensure that educators acknowledge and honor the diverse viewpoints of their student population and refrain from promoting homogeneous perspectives as universal beliefs. Glanzer (2008) referenced Hunter (2000) in that "the unspoken imperative of all moral education is to teach only those virtues, principles, and other moral teachings about which there is no disagreement in American society". Glanzer proposed that "schools should show fairness to diverse visions of the good life and not merely replace them with neutered and safe substitutes" (Glanzer, 2008). Dingus (2003) further emphasized the importance of this perspective: "No student should have to sacrifice cultural heritage, ethnic identity, and social networks in order to obtain an education".

\section{Methods}

Searching for new approaches to the study educational theory and practice evolution in national pedagogy is associated with the decision problems of educational traditions' self-determination and self-identification that emerged and developed in different socio-cultural environment, realizing their place, role and prospects. Answer to all the questions will be given in case if economic, social, political and spiritual determinants of the evolution of pedagogical phenomena in the context of the cultures and eras dialogue are comprehended, based on the data of philosophy, history, ethnography, sociology, cultural studies, anthropology, psychology, etc.

To understand and to solve this problem, it is needed to use an interdisciplinary category «civilization", which is widely used in the social sciences. On the basis of this category civilizational approach was built, which allows to understand the development of humanity in its entirety, taking into account the material and economic, spiritual and moral principles of its history, it creates the precondition to determine levels on a world historical and pedagogical process, expressing its universal properties and specifically historical characteristics. For the history of pedagogy and education of Kazakhstan the fact that "the measure of civilization process is a man, his freedom, his self-development opportunities, self-expression" is important (Osadchaya, 1991). It seems that it will let put the idea of this approach on the historical and pedagogical process, person who teaches and is taught in the center of this approach. 
In his article "Category "civilization" as a historical and methodological problem" A. Orazbayeva notes, "Identifying features of historical development, the definition of cultural originality of our nation, and its further promotion for us is "a matter of honor", we can completely eliminate the effects of cultural colonization with the assistance with it . In this case, first of all, we rely on the achievements of world science, which offered not share separate organisms and culture of primitive and advanced ones" (Orazbayeva, 2005). It is difficult to understate the complexity and drama of the controversial development process of the Kazakh spirituality during the Russian colonization. Kazakh spirituality was in constant conflict with its core values and metropolis values. Kazakh people were subordinated to the logic of another social, cultural and civilizational complex. And the conflict of values between the two cultures is a conflict of different ways of thinking, different world views and different "logics".

On the whole, we must remember that Kazakh culture, dating back to the original and distinctive branch of oriental civilization, has not lost its root identity, despite being in the field of cultural and civilizational influence of the Russian Empire. Integration processes in the modern world put on the agenda the issue of the fate of distinctive pedagogical traditions, their roots dating back centuries, the issue of the prospects of their interaction and development in the new historical conditions. The important prerequisite for the solution of these problems might be the development of a research approach that can ensure the integrity of the theoretical vision of the world historical and pedagogical process. Evolution history of pedagogy and education in Kazakhstan, as branch of knowledge, its problems, principles encourage to comprehend historical and pedagogical process from the point of view of civilizational approach.

Civilizational approach in the history of pedagogy and education in Kazakhstan contributes consideration of historical and pedagogical process with specific social and cultural patterns of Kazakh society, and on its basis determines the formulation and solution of pedagogical problems. It creates the prerequisites for the analysis of pedagogical phenomena in the context of extremely broad processes, which socializes individual, taking into account the uniqueness of the systems of social research continuity. Civilizational approach to the history of pedagogy and education is more universal, it increases the potential for scientific research, allows formulating qualitatively essential characteristics of the world education space.

In the monograph "Civilizational approach to the study of world historical and pedagogical process" G. B. Cornetov reveals the sense and meaning of civilized approach in the history of pedagogy. According to the author category "civilization" is an alternative to the formation approach in the historical and pedagogical education. It is crucial to keep up the dialectical unity of universal, general, special, single levels of the world historical and pedagogical process; to emphasize sustainable socio-cultural organisms in the history, recognize humanistic orientation of evolution of the world historical and pedagogical process. Civilizational approach allows us to understand the features of great and local civilizations; reveals the essential characteristics of a "national culture as phenomenon" (Cornetov, 1997).

Civilizational approach identifies three basic types of culture: stationary, adaptive, dynamic.

Each of these types has the characteristic traits of a particular civilization. Further we will elaborate on the civilizational approach.

In the XVIII century Mirabeau, Condorcet, Holbach considered the term "civilization" as the sociological approach.Later, in the XIX century (Morgan, Fyurgyuson, \& Engels) culturological approach was applied. This term was represented as a synonym for culture. Later, scientists had developed the concept of the local, phasic, futher world civilizations. According to this conceptual approach currently the term civilization is used in three meanings:

- As a certain socio-cultural region (local civilization);

- As a certain stage of social development (phasic civilization);

- As a global bio — and sociosystem (world civilization).

The concept "local civilization" characterizes ethnic or state certainty. Internal communications of "core" social relations, cultural traditions and ideas form specific sociocultural organisms. In this case sustainable approaches develop to formulae and resolve educational problems, which have developed within specific historical types of societies.

The concept "great civilization" is defined by a universal basis, it combines the features of lifestyle, features of the local civilizations. Great civilizations have a regional multi-ethnic character, possess a vast periphery, unique spiritual tradition. Therefore, consideration of historical and pedagogical process in this context will emphasize something special that distinguishes the theory and practice of education of the local civilizations groups. They 
can be represented in the form of basic traditions, specific to each of these civilizations. According to scientist, existing throughout history, they are considered as stereotypes, determining general parameters for the methods of formulating and solving educational issues.

History of pedagogics and education as a branch of science and practical action, having person as its object, purpose and result, refers to the formation of the three spheres of the person-the intellectual and cognitive (rational), motivational and value (emotional), moral and practical (volitional). In these basic traditions processes of initiation to the knowledge and the development of thinking, a form of motivation and behavioral skills are fixed. They focus mechanisms of socialization, reproduce, accumulate and record samples of culture and ways of its transmission from generation to generation.

Each level of civilization: a human civilization, a great civilization, a local civilization determine a certain degree of specificity of pedagogical phenomena, socio-cultural coordinates system, determines the ratio of specific and generic features of the considered phenomena. Each level has a certain meaning, its principles of historical and pedagogical process cognition, studying the world, national heritage, solving problems of theory and practice of education.

Kazakhstan is real median Euro-Asian country. In this role it consists of history, culture, religion of East and West. Consequently, the nomads, as well as sedentary people, are creators, laborers and soldiers. L. N. Gumilev and $\mathrm{O}$. Suleimenov believe that nomadic culture in its three thousand years history went through a higher level of creative evolution in comparison with the Mediterranean and Far East countries.

The term "nomadic civilization" is supported by such scientists as A. Margulan, K. Akishev, K. Baypakov. The term "nomadic society" was implemented into scientific circulation by historian D. Kshibekov.

Historically, the first types of national historical and pedagogical process originated at the time when specific features of the natural division of labor begin appear, determining all aspects of human life, including the nature and characteristics of pedagogical phenomena. Pedagogical thought, starting to stand apart from the real practice, had been developed exclusively at the level of everyday consciousness and objectified in the traditions and folklore.

According to A. Orazbayeva, any civilization can be analyzed as phasic, local and global.

Culturological approach is defined as "a set of methodological techniques, providing an analysis of any sphere of social and mental life, including education and pedagogy, through the prism of system creating cultural concepts such as culture, cultural patterns, norms and values, and way of life, cultural activities and interests, etc." (Krylova, 2000).

According Y. V. Senko, the concept "culture" until recently was not perceived by pedagogy, was not included in its scientific circulation" (Senko, 2000).

According to V. N. Rudenko, formational approach has been criticized because of the "rough sociology and determinism, the primacy of the material over the spiritual", for trying to "put a complex, contradictory rhythm of historical progress, distinguished by identity in the fates of different countries and peoples, into a Procrustean bed of dogmatic scheme" (Rudenko \& Gukalekno, 2003).

Civilizational and culturological approach as a methodological tool of pedagogy used in the analysis of relations of professional and civilizational, cultural and axiological education components.

Analysis of historical and pedagogical literature suggests that the development of pedagogy was held in a difficult interaction of different types of civilizations and cultures, characterized by their asynchrony, matchless cyclical "lifetimes", alternating advance or backlog.

In the cultural and historical context, the term "entity" in modern pedagogy is defined as "the social experience transfer in the period, time of reproduction of sustainable forms of social life in the cultural space" (Bogdanov, 1992).

In Kazakhstan, when previous ideals and values collapsed, in pedagogical science the concept "education" has been enriched by its inclusion in content of value priorities, by the depth of analysis of the essential aspects of the process. Understanding of education from the standpoint of social and cultural dynamics is consistent with its interpretation in modern pedagogical science. According to V. V. Krajewski, education appears as a "special kind of purposeful activity for the preparation of human beings to participate in social life, consisting of education activities and implemented for the benefit of man, society and the state" (Krajewski, 1996).

Culture comes from the cult, associated with the cult of the ancestors and it is impossible without sacred traditions. It is national, but civilization is international. 
Kazakh cultural studies scholars, philosophers comprehend cultural studies approach in the context of world civilization. Seidimbek, the scientist, considering the problems of the Kazakh world from the perspective of ethno-cultural understanding, gives a description of the nomadic civilization as one of the oldest. Assuming nomadic civilization as very peculiar, V. V. Radlov noted that it was unlikely, but not hostile to the culture of sedentary people era. Unlike Levshin, he had not seen the anarchy domination of Kazakhs, but only a kind of different from Russian, but in its own way quite settled cultural relations (Radlov, 1989).

Famous orientalist S. P. Tolstov wrote- - "Already in the XW century people of China, India, the Middle East and Central Asia had a notable cultural achievements, in X-XV centuries there were such giants of scientific thought as Bukharinite Ibn Sina, Kwarezmians al-Khwarizmi, al-Biruni, great poet Ferdowsi and others (Tolstov, 1962). In this galaxy of world scientific luminaries Turks occupied The place of honor: scholar and lexicographer, named as "The second teacher" after Aristotle, al-Farabi, an eminent linguist turkologist, originator of Turkology Mahmud of Kashgar, poet Yusuf Balasaguni and many others.

\section{Results}

The analysis of philosophical and pedagogical literature of recent years shows that one of the trends of modern educational paradigm in Kazakhstan is the translation of a number culture functions in the field of education and vice versa, what leads to a role strengthening of the principle of culture matching in the educational paradigm. This trend can and should be considered as the development trend of open self-developing system of modern education and should be taken into account during the creation of professional-pedagogical educational programs of the new generation, including the history of education in Kazakhstan.

Civilizational and cultural approaches provide a fundamental rethinking of the role and importance of the education system of Kazakhstan.

Civilizational approach to the construction of the education content allows analyzing pedagogical phenomena of different stages in comparative filed, also it provides considering historical-pedagogical process taking into account specifics of social and cultural patterns of Kazakhstani society.

Civilizational approach to the development of educational content allows to analyze pedagogical phenomenon of different epochs in comparative terms, facilitates the consideration of historical and pedagogical process including specific social and cultural patterns of Kazakh society.

Despite some subjectivity of civilizational approach, which manifested in the increasing of complexity and in some cases in the impossibility of synchronistic comparison and excludes the progressive development of global history, use of this approach in the realization of the real historical process allows:

1) To include human as the highest value in the process of historical knowledge;

2) To consider the material, spiritual, cultural and religious particularities of different societies in their historical continuity;

3) To overcome the Eurocentrism inherent in classical and Marxist historical science, and approve "multicultural" nature of human society (Koshelev, 1995).

The concept of a unified field of world culture raises theoretical methodological foundations and common criteria for the characteristics of the cultural phenomena that are the object field of humanitarian and general scientific field, which allows in educational research in general, in the history of pedagogy in particular being oriented in the common cultural space and adapting to unfamiliar cultural situation. Creating a unit educational and scientific-pedagogical space, as recognizing priorities of general human values will contribute to enrichment of educational traditions. Appearance of social research system allows assessing this level as universal to the other level of manifestations of historical and pedagogical process; forming general theoretical views, which become basis for an adequate study of pedagogical phenomena of present and past. Analysis of the history of pedagogy and education in the context of civilization allows revealing the essential role of pedagogical phenomena in life of people and society, in the reproduction and development of culture, also it allows determining their relation to the socialization and development of individuals.

\section{Discussion}

Considering problem arose in connection with the crisis of the concept of the information society, which has long dominated the reign of Soviet historiography, and active introduction to the science of civilization and information approaches.

Formation approach is based on the theory of Karl Marx, which is applicable only to the analysis of the socioeconomic sphere of human life associated with material production. Focusing researchers on the establishment of 
historical patterns, it provides an opportunity of diachronistic and synchronistic comparing of different stages. According to V.S. Koshelev, spread of formation approach to all spheres of historical development and giving this aspect value of unified methodological and philosophical principles, rejection of the possible existence of other approaches in the comprehension of history caused absolutisation of the category of socio-economic formation.

Due to the breakaway of the part of historians from the Marxist interpretation of the history interest to civilizational concept, developed in the writings of N. L. Danilevskiy, O. Spengler, A. Toynbee, has increased.

The "civilization" concept appeared in the XVIII century as a synonym for "culture". Enlightenment philosophers claimed that a civilized society is based on the principles of reason and justice, and it is rationally organized. In the XIX century Western European countries, joined the capitalist path of development, were called civilized.

American scientist L. Morgan in "Ancient Society" and F. Engels in "The Origin of the Family, Private Property and the State" have expanded the civilization concept. They defined it as a stage of social development, following the barbarism and associated with the birth of written language and the emergence of cities (Marx \& Engels6, 1955).

To determine the essence of the concept "civilization" scientists use different terms: the soul (Spengler), style (Toynbee), central meaning or mentality (Sorokin), ethnicity (Begbi), the mass consciousness (Douson), collective consciousness (Uekost), worldview (Richardson), etc.

However, consideration of civilization as a world- historical community has been challenged in the work of sociologist Y. Danilevskiy "Russia and Europe". He verbalized the idea of local and separate "cultural and historical types" or "civilizations". They are like living organisms go through the stages of birth, maturity, senescence and death (extinction or degradation) (Danilevsky, 1869).

Oswald Spengler, German philosopher, in 1918 in two volume book "Der Untergang des Abendlandes" offered his vision. According to this, history of mankind is in the form of eight closed cultures - "organisms". According to Spengler, every culture in its development passes the millennial cycle and turns into civilization though "dying". Philosopher understood civilization as mechanical form of the living culture that has dead "length" and soulless "intelligence". He considered the development of technology and industry, the decline (decadence) of art and literature, the emergence of large cities, populated by faceless gray masses, i.e. transition to a "mass society" as the main signs of civilization (Spengler, 1923).

Thus, philosopher considers the history as original and primordial form of life experience, which doesn't have anything in common with science. According to the German scientists, history is a sequence of closed cultural formations. Each of the cultures has a special character, manifested in different aspects of their life and development, but they pass the same cycle. Spengler dissolves history in the lives of civilizations, each of which is born, grows, matures, withers and dies, and that, what determines its origin and the changes, disappearance stems from its own nature. In his view, what interesting is that he captures not only the phases of the cyclical development of culture, but also their duration. The author combines the idea of isolation of local structures with the theory of cultural and historical cycles.

In the twelve-volume work "A Study of History" British scholar Arnold Toynbee noted that the subject of historical research is the life of human societies. He shares the story of humanity on a number of local civilizations (primary, secondary and tertiary), having the same internal circuitry, or the functional law of development. Toynbee considered "creative minority" (carrier of "elan vital") as the driving force of civilization (Toynbee, 1991).

There are many similarities in the views of Spengler and Toynbee. The main difference is that Spengler's cultures are completely isolated from each other. There are relationships of cultures, isolated in space and time, and only historian can make the similarities between them.

Toynbee's relations have an external in nature, but form part of the lives of these civilizations. It is extremely important for him, that some societies provide continuity of the historical process, joining others.

L. N. Gumilyev, the historian, gave civilization traits to each separate ethnic group (Gumilev, 1989).

N. S. Rozov's definition is very interesting-“Civilization is a historically stable set of ethnic groups that has writing and statehood, related by unity of social relations, cultural traditions and ideas" (Rozova, 1992).

\section{Conclusion}

It is impossible to disclose research issue due to requirements of volume and complication of this issue. 
Moreover, this issue is new and not deeply searched.

In the framework of modern historical and culturological problems historically rooted culture contains special information structures, which, on the one hand, provide system management, its self-regulation, and on the other hand, reflect sufficient information about the culture in the context of educational models building, it should be noted that evolution of these models must comply with the basic phases of the evolution characteristics of culture. This position is crucial in today's national education modernization, as it determines the main direction of its development.

Analyzing these statements, we can definitely say that education is intended to provide an understanding of the entirety of life, the assimilation of cultural achievements accumulated by mankind. Perceived values, the laws of nature and society development, the acquired skills of the various activities, including educational, creative, constructive, used in various fields of life and in the teaching practice. Thus, functions of culture relate to the functions of education and they should be considered as similar.

\section{References}

Ambrosio, J. (2003). We make the road by walking. In G. Geneva (Ed.), Becoming multicultual educators: Personal Journey toward professional agency (pp. 17-41). San Francisco: Jossey-Bass.

Bogdanov, I. V. (1992). Local educational system: Experience in design, establishment and development (p. 256). Togliatti.

Cornetov, B. G. (1997). World History of Pedagogy: An anthropological approach (Vol. 6, pp. 13-22). Magistr.

Danilevsky, N. Y. (1869). Russia and Europe. Look at the cultural and political relations of the Slavic world to the German- Romanesque (p. 115). St. Petersburg.

Dingus, J. (2003). Making and breaking ethnic masks. In G. Gay (Ed.), Becoming multicultual educators: Personal journey toward professional agency (pp. 91-116). San Francisco: Jossey-Bass.

Gay, G. (2000). Culturally responsive teaching: Theory, research, and practice. New York: Teachers College Press.

Gay, G. (2006). Connections between classroom management and culturally responsive teaching. In C. M. Evertson, \& C. S. Weinstein (Eds.), Handbook of classroom management: Research, practice, and contemporary issues (pp. 343-370). Mahwah, NJ: Erlbaum.

Glanzer, P. L. (2008). Harry Potter's provocative moral world: Is there a place for good and evil in moral education. Kappan, 89(7), 525-528. http://dx.doi.org/10.1177/003172170808900716

Gumilev, L. N. (1989). Ethnogenesis and the Biosphere (p. 182). Leningrad: Leningrad State University.

Hackett, T. (2003). Teaching them through who they are. In G. Gay (Ed.), Becoming multicultual educators: Personal journey toward professional agency (pp. 315-340). San Francisco: Jossey-Bass.

Hrapchenkov, G. M., \& Hrapchenkov, V. G. (1998). History of school and pedagogical thought of Kazakhstan (p. 168). Almaty: University Kainar.

Hunter, J. D. (2000). The death of character: Moral education in an age without good and evil. In G. Gay (Ed.), Becoming multicultual educators: Personal journey toward professional agency (pp. 117-142). San Francisco: Jossey-Bass.

Kornetov, G. B. (1994). Civilizational approach to the study of world historical and pedagogical process (p. 250). Moscow.

Koshelev, V. S. (1995). Crisis in modern historical science. Gistarychnaya Navuka i gistarychnaya adukatsyya $\tilde{y}$ Respublitsy Belarus, $2,9$.

Krajewski, V. V. (1996). Pedagogical theory: What is it? Why do we need it? How is it done (p. 154)? Volgograd.

Krylova, N. B. (2000). Culturology of Education (p. 269). Moscow: Narodnoe obrazovaniye.

Ladson-Billings, G. (2001). Crossing over to Canaan: The journey of new teachers in diverse classrooms. San Francisco: Jossey-Bass.

Marx, K., Engels, F., Marx, K., \& Engels. (n.d.). Collected works, 21, 178.

Orazbayeva, A. (2005). Nomads civilization of the Eurasian steppes. Institute of Oriental Studies named after $R$. $B$ (p. 310). Suleimenov. Almaty: Daik-Press. 
Osadchaya, I. O. (1991). About civilizational aph to the analysis of capitalism. World economics and international relations, 5,7 .

Osadchaya, I. O. (1991). Civilizational approach to the analysis of capitalism. World Economy and International Relations, 5, 7.

Pozdnyakov, E. (1990). Formational civilizational approaches. Economic and international relations, 5, 53.

Radlov, V. V. (1989). From Siberia. Diary pages (p. 249). Moscow.

Rozova, N. S. (1992). Structure of civilizations and world trends (pp. 88-89). Novosibirsk.

Rudenko, V. N., \& Gukalekno, O. V. (2003). Civilizational and cultural development paradigm of university education. Pedagogika, 6, 45

Senko, Y. V. (2000). Humanitarian basis of teacher education (p. 145). Moscow.

Spengler, O. (1923). Decline of the West (p. 157). SPb.

Taubayeva, S. T. (2007). Introduction to the methodology and methods of pedagogical research (p. 190). Turkestan: Turan.

Tolstov, S. P. (1962). According to the ancient delta of the Oxus and Jaxartes (p. 62). Moscow.

Toynbee, A. J. (1991). A Study of History (p. 270). Moscow: Progress Publishers.

Trumbull, E. (2005). Language, culture, and society. In E. Trumbull, \& B. Farr (Eds.), Language and learning: What teachers need to know (pp. 33-72). Norwood, MA: Christopher-Gordon.

Weinstein, C., Curran, M., \& Tomlinson-Clarke, S. (2003). Culturally responsive classroom management: Awareness into action. Theory into Practice, 42(3), 269-276. http://dx.doi.org/10.1207/s15430421tip4204_2

\section{Copyrights}

Copyright for this article is retained by the author(s), with first publication rights granted to the journal.

This is an open-access article distributed under the terms and conditions of the Creative Commons Attribution license (http://creativecommons.org/licenses/by/3.0/). 